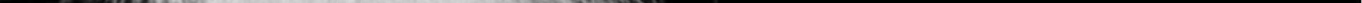


Previous page: Bette Davis in 20,000 Years in Sing Sing (1932) (Courtesy Getty Images) 


\title{
James Baldwin and Film Beyond the American Century
}

Robert Jackson University of Tulsa

\begin{abstract}
This article provides an introduction to this special section of James Baldwin Review 7 devoted to Baldwin and film. Jackson considers Baldwin's distinct approach to film criticism by pairing him with James Agee, another writer who wrote fiction as well as nonfiction in several genres, and who produced a large body of film criticism, especially during the 1940s. While Agee, a white southerner born almost a generation before Baldwin, might seem an unlikely figure to place alongside Baldwin, the two shared a great deal in terms of temperament and vision, and their film writings reveal a great deal of consensus in their diagnoses of American pathologies. Another important context for Baldwin's complex relationship to film is television, which became a dominant media form during the 1950s and exerted a great influence upon both the mainstream reception of the civil rights movement and Baldwin's reception as a public intellectual from the early 1960s to the end of his life. Finally, the introduction briefly discusses the articles that constitute this special section.
\end{abstract}

Keywords: James Baldwin, James Agee, film criticism, television, race, civil rights movement 
$I$, nevertheless, was the eldest, a responsibility I did not intend to fail, and my first conscious calculation as to how to go about defeating the world's intentions for me and mine began on that Saturday afternoon in what we called the movies, but which was actually my first entrance into the cinema of my mind.

James Baldwin, The Devil Finds Work ${ }^{1}$

To see his two loves, movies and books, fused together was, I believe, one of the great ambitions of his life. I'm sure that if pressed Jimmy would have admitted that he craved an Oscar almost as much as he did a Pulitzer. Yet he found a way to participate vicariously in the cinema and he certainly found a way to live in the glamorous lifestyle of its leading actors. But-and this is to his great credit-despite his many frustrations and disappointments, not all of which, by any means, could be attributed to his disdain for legal paperwork, Jimmy never lost his innocent pleasure in the cinema.

Caryl Phillips, A New World Order ${ }^{2}$

Derhaps it's simply that I see the world differently just now, having recently survived 2020, a plague year in several senses of the word. But even the usual line, that James Baldwin is an essential writer for our time, feels inadequate, shallow. More than that, though, I find myself musing on our ability to see more deeply into the world when we are living through a crucible of some sort-a pandemic, a reign of terror, a freedom struggle. Not so much a crisis of what Rob Nixon has called slow violence, since that might leave the trauma invisible to the naked eye; but just the reverse, a crisis that clarifies and orders the workings of the world into a spectacle, one whose pattern, whose raw dramatic power, had not always been so plain to witness in ordinary time. ${ }^{3}$

The film writer who most reminds me, just now, of Baldwin is James Agee, and there is a part of me that is surprised that I hadn't made the connection earlier. There are, of course, reasons why the two wouldn't be grouped together. They never met personally; one arrived as a public figure not long before the other departed. Baldwin, fifteen years younger, was a wide-eyed student of the early sound era of the 1930s. Agee's birth year, 1909, made him a child of the silent era, and left him captivated for his too-brief life by such fossils as Charlie Chaplin and Buster Keaton, and by the film he considered the greatest of all time-or, as he put it, "the one great epic, tragic film": D. W. Griffith's The Birth of a Nation (1915). Of the same film, an unfortunate but inexorable fact of history which to Baldwin had "the Niagara force of an obsession"- a phrase Agee likely would have appreciated, despite the chasm between the two men in what they took from the film-Baldwin put it bluntly: "The Birth of a Nation is really an elaborate justification of mass murder." ${ }^{\prime}$ How could these men be reconciled?

When Agee looked at motion pictures, even during his run as a film critic for Time and The Nation in the 1940s, he did so in much the way the old silent directors who flourished in the sound era did-King Vidor, John Ford, Alfred 
Hitchcock, René Clair, Fritz Lang, Ernst Lubitsch, and Chaplin himself. Which is to say, he continued to see silent films, even when they spoke, sang, or otherwise made noise. But Agee was not-or not simply_an antiquarian, nor a primitivist; he longed for something new, if it could cut through the malaise of the business. "Music can be well used in movies," he wrote in 1945:

and indeed I think the greatest possibilities have hardly yet been touched. But music is just as damaging to nearly all fiction films as to nearly all fact films, as it is generally used in both today. Its ability to bind together a succession of images, or to make transitions between blocks of them-not to mention "transitional" and "specialeffect" and "montage" passages-inevitably makes for laziness or for slackened imagination in making the images and setting them in order, and in watching them. Still worse, it weakens the emotional imagination both of maker and onlooker, and makes it virtually impossible to communicate or receive ideas. It sells too cheaply and far too sensually all the things it is the business of the screen itself to present. The rough equivalent might be a poet who could dare to read aloud from his own work only if the lights were dimmed and some Debussy was on, very low. ${ }^{6}$

This is a passage, not atypical of Agee in his film writing, of diagnosis. His attitude toward the broad run of film he was required to sit through week after week is one of nearly exhausted patience. And while those bygone days are never mentioned, it is clear that the old knowledge, the intricately grained memory of the silents, and Agee's loyalty to that memory, have shaped his identity and vision as few other experiences did or could. This is the task Agee set out for himself: to articulate an ideal of aesthetic dignity and possibility, and in doing so to take the whole industry to task for failing to honor it, or indeed, even to understand its existence. Agee is after honesty, emotional truth, maturity; what he finds instead, all too frequently, is corruption. "Laziness" and "slackened imagination," a weakened "emotional imagination" that is shared by auteur and viewer alike-these are not simply lapses by the purveyors of popular entertainment, but signs of moral failure and dehumanization.

And here, despite their differences in age and race and so much else, is where Agee and Baldwin come together. "Slackened imagination" might well have been one of Baldwin's phrases, pertaining not simply to the movies' impact on the emotional lives of moviegoers but also to the atrophied inner lives of Americans across all their works and days. In this respect, Baldwin's litany of Hollywood's underachievement in The Devil Finds Work (1976), a long personal history of moviegoing littered with painful knowledge and thwarted love, is entirely of a piece with his jeremiads against religious hypocrisy and militant ignorance in The Fire Next Time (1963). "It is the innocence which constitutes the crime," he wrote in the latter book; and Agee, had he survived to read the words, would have understood and agreed: for he had said much the same thing across the years of his film reviews. $^{7}$

It strikes me as well, in these after times of 2021, that each man had his crucible. ${ }^{8}$ Both of these events arrived at nearly the same moment in their lives, around 
the age of thirty. For Agee, it was World War II; for Baldwin, the civil rights movement. Both men identify a deeply American strain of dishonesty and evasion, of lethal sentimentality, of mass-market conformity that leads to poor habits of mind and heart. These are, in the judgment of both writers, mortal sins. Late in 1943, Agee warned of America's "unique and constantly intensifying schizophrenia

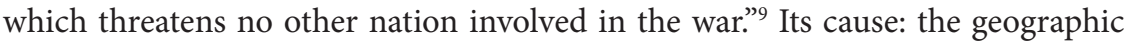
isolation of Americans from the battlefields, which was making the entire nation, already "a peculiarly neurotic people," even less capable of confronting the realities of the world. ${ }^{10}$ "Our predicament is bad enough as it stands," Agee lamented; "the civil and international prospect is unimaginably sinister." 11 Such worries were all in a week's work; Agee's column addressed the squandered opportunities of American motion pictures, from obscure Army Orientation films to Hollywood frauds like The North Star (1943)_ "something to be seen more in sorrow than in anger and more in the attitude of the diagnostician than in any emotion at all" - to enlist the intelligence and courage of their audience. ${ }^{12}$ Of such hokum Agee wrote pessimistically: "I am afraid the general public will swallow it whole. I insist, however, that the public must and can be trusted and reached with a kind of honesty difficult, in so mental-hospital a situation, to contrive; impossible, perhaps, among the complicated pressures and self-defensive virtuosities of the great studios." ${ }^{33}$ For Baldwin, similar sentiments more frequently included his analyses of race, a topic that consumed him, but the conclusion was the same: Americans were almost hopelessly addicted to the "corroboration"- a term he used over and over againof their own fantasies, prejudices, and childish expectations. ${ }^{14} \mathrm{He}$ himself might have borrowed Agee's lines to describe The Defiant Ones (1958), an absurd fantasy of the unconditional Black love that exists for white people, or The Exorcist (1973), a horror film most frightening for "the mindless and hysterical banality of the evil" it presents even as it evades the much deeper and more threatening evil that resides as potential within all of us. ${ }^{15}$ Unlike most of their fellow citizens-that is, if the evidence of American culture and institutions were to be considered-Agee and Baldwin apprehended a moral urgency in the quotidian matter of lived, and living, history.

As Agee's columns accumulated in the 1940s and Baldwin developed the half-century story of his life at the movies in The Devil Finds Work in the 1970s, both struggled to keep their ideals intact in the face of so much terrible product, even as they shared a childlike faith in the possibilities of the form itself. Their continuing to show up for work, armed with the hope of encountering something humane and transformative, is all the more impressive because of their investment in a popular form rather than a "high" one. The sordid origins and heavy-fisted proprietors of the industry, as well as the enormous proletarian audiences of the movies, added, paradoxically, to their import. This was not so much by choice as by inheritance.

They reveled in the lowest of genres, from slapstick to soap opera. Agee, in his truncated childhood in the hills of east Tennessee, and Baldwin, in his own Harlem predicament as a young boy, both discovered almost as early as they could see 
that they had as much access to this world of light and shadow as anyone else did. Agee grew into himself in his earliest memories sitting in the dark next to his father (whom he would lose in 1915) as they took in Chaplin's sacred pratfalls. With the very space of the theater marking the yawning distance between Baldwin and his holy, disapproving father, the very young Baldwin lived, comparably, in the orbit of Bette Davis's ferocious gaze in 20,000 Years in Sing Sing (1932), the same gaze featured on this special section's opener. With her "pop-eyes popping," he saw his own face, and incipient ferocity, reflected. "I had discovered that my infirmity might not be my doom," he writes. "My infirmity, or infirmities, might be forged into weapons." ${ }^{17}$ Through this disquieting white starlet, who ran the gamut from ingénue to femme fatale-usually all at once-he began to fathom his own multiplicity. A decade later, he writes, Davis's performance as a spoiled southern belle who debases herself before her Black chauffeur in In This Our Life (1942) "had the effect, rather, of exposing and shattering the film, so that she played in a kind of vacuum." ${ }^{18}$ Davis became "the toast of Harlem," for she graphically exposed the white racial hypocrisy that American culture-not least of all, the Hollywood assembly line-worked tirelessly to hide:

The blacks have a song which says, I can't believe what you say, because I see what you do. No American film, relating to blacks, can possibly incorporate this observation. This observation-set to music, as are so many black observations-denies, simply, the validity of the legend which is responsible for these films: films which exist for the sole purpose of perpetuating the legend. ${ }^{19}$

With "the truth about the woman revealed," Baldwin writes, Davis has pierced through this institutionalized racial mythology from the inside, reminding him of the possibilities of subversion and humanization latent in American film. ${ }^{20}$ Baldwin's highest compliment to Davis—a phrase Agee might well have written-was to describe her performance of southern white womanhood as "ruthlessly accurate."21

For both writers, and irreversibly, the cinema challenged and supplanted the church; and just as both men lapsed in the formal religious lives they had been assigned as children, and became, somehow, more devout in their apostasy and profanity, their faith in the cinema deepened with each holy horror they encountered on the screen. For both men, the promise of the cinema remained, not unlike the "New Jerusalem" that Baldwin insisted, against all the violent evidence of American history, could still be wrought by people who groped across the abyss that divided them..$^{22}$

They both forged a wicked sense of humor, and it accompanied them like a shield through the lonelier stretches, which were frequent. Agee eventually self-destructed, succumbing to a heart attack in 1955. His fall may have been accelerated by several years of journeyman's work as a screenwriter, when he enjoyed the mainstream success that came far more easily to white writers in Jim Crow Hollywood than to those seen as non-white. Enjoyment, for Agee, was no 
simple matter, however, and might well consist of compulsive overwork, impossibly high aesthetic expectations, and dangerous sorts of self-medication. Baldwin himself, despite a series of near misses in Hollywood and elsewhere, never abandoned the hope of producing his own films. His sensitivity left him vulnerable, too, especially in a Hollywood setting in which he was hired, in 1968, to imagine Malcolm X not as a friend he had known and mourned but as a generic, and substantially deracinated, action hero. (Charlton Heston, riding high on the success of Planet of the Apes (1968), was among the list of names producers suggested for the title role. Baldwin, reading the writing on the studio wall, took his screenplay and left town.) Despite his own occasional self-destructive impulses, Baldwin had other compulsions, too, including his involvement in the civil rights movement, and a wide network of friends, family, and more than a few movie stars, which drew him beyond himself in ways that sustained him. And he understood his fame, in part, as an opportunity not simply to muse on the jagged pattern of history in front of an audience, but to intervene in that history in direct ways that might alter its course for the better. "There is never time in the future in which we will work out our salvation," he wrote in the late 1950s, not about film or celebrity, but about the freedom struggle. "The challenge is in the moment, the time is always now."23 The show, and the struggle, must go on, with Baldwin as producer as much as star.

Agee had rather less the street activist in him; and his death in 1955 delivered him from the more activist years of the struggle to come. But he, too-and in ways that Baldwin might have appreciated-had a sort of stage presence, and strained to do his part. He chafed under the impositions of Henry Luce, the mogul who employed him as a staff writer at Fortune and Time. Luce revealed his own priorities in "The American Century" (1941), a Life editorial in which he advocated an updated, but not really new, model of American nationalism and imperialism, in which the United States should use the world crisis of the moment to establish itself at the center of the global order. Indeed, Agee's chronic depression might be read as the cost of his ongoing exposure to Luce's all-American brew of military might and earnest shallowness. Working for Luce at Fortune in the 1930s, Agee said, left him with feelings ranging from "a hard masochistic liking to direct nausea." ${ }^{24} \mathrm{~A}$ typical reply came in the form of Agee's almost mystically reverent treatment of Alabama tenant farmers in a routine Fortune assignment; deemed completely unsuitable for publication in a business magazine, this work became the basis for Agee's classic collaboration with photographer Walker Evans, Let Us Now Praise Famous Men (1941). Agee also articulated his support for civil rights legislation, as he wrote to his former teacher and mentor Father James Flye in May 1945: "I dislike the forms of discrimination which this kind of legislation is trying to combat. There are very few ways of combatting it, and on the whole I am afraid they are worse than useless; but such as the ways are, and poor as they are, I am for them. ${ }^{25}$ Such a stance as this might have been surprising ten or even twenty years later among most white southerners. In the 1940s it was utterly remarkable; and coming from the same writer who would publish a lengthy tribute to D. W. Griffith 
in 1948, insisting that the late Griffith, in making The Birth of a Nation, had gone "to almost preposterous lengths to be fair to the Negroes as he understood them," and defending Griffith against the calumnies of the "contemporary abolitionists," Agee's antiracism takes on an almost surreal quality. ${ }^{26}$ Perhaps, though-and again, in ways Baldwin would recognize-it was more instinctive than intentional, the expression of an uncomplicated humanism in a complicated world.

In the last year of World War II, Agee wrote to Father Flye of his halcyon vision:

I begin to want to write a weekly column for some newspaper or magazine-very miscellaneous but in general, detailed topical analysis of the very swift and sinister decline and perversion of all that might be meant by individualism, a sense of evil, a sense of tragedy, a sense of moral vigilance or discrimination; the perversion of virtually all nominal rationalism to the most irrational sort of uses and ends; the fear of the so-called irrational, the mock-revival of mock-religion; and well, etc. etc. ${ }^{27}$

To a great extent, this miscellany is what he was already producing in his film criticism, especially in the longer reviews for The Nation, but even, with some regularity, in the haiku-like buckshot of his Time coverage. Agee's film writing provided persistent autobiographical traces of the sort that left little doubt as to the tenacity of his perception and belief. "Decline and perversion" were mere evidence of the potential for human grandeur; "evil" and "tragedy," reminders of the dignity of man; "moral vigilance," the highest aim of his work. So too with Baldwin, whose ambition and commitment are everywhere in these lines. From backgrounds starkly different-or perhaps not-these men shared a civilization in flight from itself, and as they bore witness to its misdeeds and attempted escapes, they suffered dearly for the insights they carried within themselves.

My own halcyon vision, tailored to my own after times: to discover in the archives some grainy old television footage, the two of them sitting at the table and talking movies, shaking their heads in disbelief and amusement, shoring up their shared humanism, and ours-the New Jerusalem on celluloid.

Film is such a big topic in Baldwin's life and career that it can almost be invisible at times, like geological time or climate change or some other pattern whose scale renders it, most of the time, invisible. He had a lifelong relationship with the movies, a relationship every bit as complicated as his relationships with literature and with many of the people in his family and inner circle. Baldwin's relationship with film, meanwhile, is not just one thing; it takes many forms, and it changes a great deal over the course of his life. What's more, it seems to have changed considerably, or we have changed enough to see it anew, in the decades since his death.

Baldwin's career also coincided with the rise of television, which necessarily transformed his relationship with the movies of his youth. Television was met with utopian fantasies by some Blacks who knew the indignities of the Jim Crow studio 
system all too well. Perhaps the new medium, which was not subject to the same forces of censorship and self-regulation that had contorted the Black face into a grotesque minstrel rictus, would bring about better portraits of Black lives, and better opportunities for Black performers. This was a widely shared hope at mid-century, just as Baldwin was beginning to publish his writing. Baldwin's celebrity in the following years would owe a great deal to his television appearances, which were numerous and varied, and went well beyond the talk-show circuit: from his 1963 interview with Kenneth Clark on New York's WGBH to Take This Hammer (1964), produced for national broadcast by San Francisco's KQED; from his 1965 debate with William F. Buckley at Cambridge to his spirited repartee with Dick Gregory and West Indian students in London in Baldwin's Nigger (1968). And even as Baldwin's fiction and drama went unproduced by Hollywood, there were several television adaptations of his work, from a Germanlanguage production of his play Blues für Mister Charlie (1969), which was filmed in Vienna, to the PBS production of Go Tell It on the Mountain (1985) that Baldwin enjoyed not least because it received prominent coverage in that all-important organ of American intellectual life, TV Guide.

Television created an identity crisis for Hollywood, and over the course of the 1960s and 1970s the movies struggled to reinvent themselves amid the very forces of American discontent that Baldwin was documenting in his writings and television appearances. While The Devil Finds Work did not address television in much detail or explicitness, it was published during a major upheaval in American cinema, and Baldwin experienced the moment as an opportunity-yet another one, as the civil rights movement had been-slipping away. The studios struggled with bankruptcies. Longtime industry leaders no longer trusted themselves to predict what audiences wanted to watch, even as televised images of civil rights protests and the Vietnam War were broadcast, daily, into the living rooms of millions of Americans. An insurgency of film school brats and other outsiders seized the opening and became "canonical" in due time: Francis Ford Coppola, George Lucas, Steven Spielberg, Woody Allen, Martin Scorsese, Hal Ashby, Robert Altman; but also the likes Melvin Van Peebles and Gordon Parks, who proved considerably more bankable than the radical, genre-defying L.A. Rebellion cohort coming out of UCLA. Television exerted its own gravitational force, providing a venue for commentary and critique of Hollywood's mythology even as it shaped Hollywood simply by virtue of its own huge presence in American life. In the context of this blue light, Baldwin's appearances on The Dick Cavett Show, in which he continued to disturb the peace amid an early 1970s hangover of benign neglect, suggest that television, more than the big screen, may have been his most apt medium, even as he pined for that elusive Oscar. This was appropriate, too, in the sense that television had served, far better than the cinema, as the medium of the civil rights movement. Baldwin washed his hands of Hollywood's adaptation of, and to, civil rights in such evasive, snail-paced vehicles as In the Heat of the Night and Guess Who's Coming to Dinner (both 1967). Meanwhile, and despite his occasional reservations about the lethally reassuring presence of television in 
American life, he seized the opening it offered, becoming a small-screen provocateur and flâneur, a troubling, charming, witness-bearing, truth-telling visitor from that singular world of his own making - the cinema of his mind.

The idea for this special section emerged from a roundtable at the Modern Language Association's conference in Seattle, which took place in January 2020, a few weeks before Covid precipitated our long isolation. That session, "Finding Work for the Devil: James Baldwin on Film," included the participation of Rich Blint, Justin A. Joyce, Quentin Miller, Karen Thorsen, and myself, and spurred a series of conversations among various attendees and ourselves in subsequent weeks and months. Over the course of an exceptionally tumultuous and difficult year, these articles were written.

Karen Thorsen's “The Disorder of Life: James Baldwin on My Shoulder, Part Two," is the second serialization of her memoir; "Part One" was published in volume 6 of James Baldwin Review. Thorsen directed James Baldwin: The Price of the Ticket (1990) after plans to collaborate on a film with Baldwin were interrupted by his terminal illness in 1987. This second part of her memoir offers an invaluable look at Baldwin's late-career views of his work, in print and in action, and also on film, since the civil rights era. It is also a portrait of Baldwin's interest in young people, their aspirations and ideals, as he aged and reflected on his own youth. Thorsen's own quest had taken her to France, to Vietnam, and, in a rather unlikely way, into the orbit of the great cinéma vérité filmmakers Albert and David Maysles, where she forged a filmmaking career of her own. Her account makes it clear that Baldwin, at the point of their meeting, valued her wide-ranging curiosity about the world, and her model of social commitment in the face of contemporary global affairs, at least as much as he cared about her background in film.

In "The Devil Finds Work: A Hollywood Love Story (as Written by James Baldwin)," D. Quentin Miller revisits this most vexing of Baldwin's books. Many readers have struggled to classify The Devil Finds Work, and have ended up comparing it, usually unfavorably, to earlier works - and particularly to The Fire Next Time, an extended essay that likewise combines memoir with other modes of storytelling and analysis in the service of larger claims regarding race, culture, and American citizenship. Miller breaks with this critical tradition, suggesting instead that a more apt comparison may be to Baldwin's fiction. The "love story" in Baldwin's long relationship with the movies, he finds, has striking parallels with the love story in Giovanni's Room (1956), Baldwin's second novel. In seeing The Devil Finds Work as the story of a failed love affair, Miller positions Baldwin's film criticism anew, and reads across Baldwin's multifaceted career a larger sense of coherence and integration.

In "Another Cinema: James Baldwin's Search for a New Film Form," Hayley O'Malley combines readings of archival documents, literature, film, and print culture to examine three distinct modes in Baldwin's ongoing quest to revolutionize 
film for his own purposes. Literature, she argues, served as a key site to practice being a filmmaker. Beginning as early as Go Tell It on the Mountain (1953), Baldwin adapted cinematic grammars in his fiction and portrayed moviegoing in such a way that he could, in effect, direct his own movies, turning the novel and the short story into alternative genres of filmmaking. In the 1960s, Baldwin took a more direct route to making movies, as he composed screenplays, formed several production companies, and attempted to work in both Hollywood and the independent film scene in Europe. Finally, O'Malley explores how Baldwin sought to change cinema not only by trying to work behind the camera, but also by performing in front of it, in particular during his collaboration on Dick Fontaine and Pat Hartley's documentary I Heard It Through the Grapevine (1982). This littleknown film follows Baldwin as he revisits key sites from the civil rights movement and reconnects with activist friends as he endeavors to construct a revisionist history of race in America and to develop a media practice capable of honoring Black communities.

Peter Lurie's “Everybody's Protest Cinema: Baldwin, Racial Melancholy, and the Black Middle Ground" uses Baldwin's 1949 critique of the protest novel to consider its corollary in the 1990s New Black Cinema. Reading that tradition, and particularly Spike Lee's Malcolm X (1992), against more recent films by Barry Jenkins and the collaboration of Joe Talbot and Jimmy Fails, Lurie argues for the resurgent importance of Baldwin's critical model and its ethics as well as his aesthetics across the three decades since Malcolm $X$ emerged as perhaps the most influential Black film of its time. Jenkins's adaption of If Beale Street Could Talk (2018) and Talbot and Fails's The Last Black Man in San Francisco (2019) offer a cinematic version of racial narrative at odds with the protest tradition Lurie associates with Lee and other earlier Black directors, a cinema we may see as both a direct and an indirect legacy of Baldwin's views on African American culture.

In one of his last television appearances, a December 1986 C-SPAN broadcast of Baldwin's speech at the National Press Club in Washington, DC, he was asked his opinion of a new film called She's Gotta Have It. The crowd, and Baldwin, giggled at the mention of the title-a moment of levity in the midst of hard questions about the Cold War, South Africa, and African American history. With a grin, Baldwin said he hadn't seen it. Nor would he live to see the enormous, rich tradition of African American cinema that has been produced since those early films of Spike Lee were released. It is a body of filmmaking that continues to revealperhaps more now than ever, as Peter Lurie senses-Baldwin's abiding influence upon the thought and expression of contemporary Black culture.

Baldwin did, however, call forth a vision of historical continuity in his speech, implicating the institutions of American film in an ignoble past that continued to shape the present:

We can see if we examine our legends that very shortly after I was discovered in Africa, where I was the sometimes noble savage, in the twinkling of an eye, after the Middle Passage, I am found on the Metro-Goldwyn-Mayer backlot, singing and 
dancing, the noble savage now transformed into the happy darky. No one quite knows how this happened. We are living with these myths until today. And it corrupts the view from here. ${ }^{28}$

His closing remarks that day, some of the last lines he delivered before a camera, considered these tired, racist images even as they hinted at other possible futures. Baldwin had survived the American century long enough to witness how disastrously white supremacy in domestic affairs, including those of Hollywood, had stunted American understanding of the rest of the world. He wanted to hope for something else:

The reason it is important now is that, out of this endeavor, what we call the white American has created only the nigger he wants to see. The reason that's important and terrifying and corrupts the view from here is because when this same white man looks around the world, he sees only the nigger he wants to see. And that is mortally dangerous for the future of this country, for our present fortunes. The world is full of all kinds of people who live quite beyond the confines of the American imagination and who have nothing whatever to do with the guilt-ridden vision of the world which controls so much of our life and our thinking, and which paralyzes very nearly our moral sense. We are living in a world in which everybody and everything is interdependent. It is not white, this world. It is not black either. The future of this world depends on everyone in this room, and that future depends on to what extent and by what means we liberate ourselves from a vocabulary which now cannot bear the weight of reality. Thank you. ${ }^{29}$

I hope that $J B R$ readers will receive this special section's scholarship in the Baldwinian spirit in which it has been produced: for even as it speaks in urgent ways to the problems of the present, it is hardly the last word in the conversation. The scale and complexity of Baldwin's relationship with film, and the as-yet-unproduced nature of the future, make it so. I know that there will be a great deal more for all of us, individually and collaboratively, to say and do, as we seek to bend these after times to good purpose, as we attempt, several decades late, to trade in the American century for something better.

\section{Notes}

1 James Baldwin, The Devil Finds Work (1976), in Collected Essays, ed. Toni Morrison (New York, Library of America, 1998), p. 483.

2 Caryl Phillips, "James Baldwin: The Lure of Hollywood," in A New World Order (New York, Vintage, 2002), p. 74.

3 See Rob Nixon, Slow Violence and the Environmentalism of the Poor (Cambridge, MA, Harvard University Press, 2013).

4 James Agee, Agee on Film: Criticism and Comment on the Movies (New York, Modern Library, 2000), p. 313.

5 Baldwin, The Devil Finds Work, p. 511. 
6 Agee, Agee on Film, p. 153.

7 James Baldwin, The Fire Next Time, in Morrison (ed.), Collected Essays, p. 292.

8 Here I follow Eddie S. Glaude, Jr., who, contemplating Baldwin's moral imagination after the civil rights movement, borrows the phrase "after times" from Walt Whitman. See Eddie S. Glaude, Jr., Begin Again: James Baldwin's America and Its Urgent Lessons for Our Own (New York, Crown, 2020), pp. 16-17.

9 Agee, Agee on Film, p. 38.

10 Ibid., p. 39.

11 Ibid.

12 Ibid., p. 40.

13 Ibid., p. 41.

14 For one of many such examples, see Baldwin, The Devil Finds Work, p. 500: "That the movie star is an 'escape' personality indicates one of the irreducible dangers to which the moviegoer is exposed: the danger of surrendering to the corroboration of one's fantasies as they are thrown back from the screen."

15 Baldwin, The Devil Finds Work, p. 571.

16 Ibid., p. 482.

17 Ibid., p. 483.

18 Ibid., p. 522.

19 Ibid., pp. 521, 522.

20 Ibid., p. 521.

21 Ibid., pp. 522-3.

22 See Karen Thorsen (dir.), James Baldwin: The Price of the Ticket (Maysles Films \& PBS/ American Masters, 1990).

23 James Baldwin, "Faulkner and Desegregation," in Morrison (ed.), Collected Essays, p. 214.

24 Alan Brinkley, The Publisher: Henry Luce and His American Century (New York, Vintage, 2010), p. 163.

25 James Agee, Letters of James Agee to Father Flye (New York, Ballantine, 2nd ed., 1971), p. 146.

26 Agee, Agee on Film, p. 313.

27 Agee, Letters of James Agee to Father Flye, pp. 141-2.

28 The World I Never Made, C-SPAN (10 December 1986), www.c-span.org/ video/?150875-1/world-made (accessed 24 April 2021).

29 Ibid.

\section{Works Cited}

Agee, James, Agee on Film: Criticism and Comment on the Movies (New York, Modern Library, 2000).

Letters of James Agee to Father Flye (New York, Ballantine, 2nd ed., 1971).

Baldwin, James, The Devil Finds Work (1976), in Collected Essays, ed. Toni Morrison (New York, Library of America, 1998), pp. 477-572.

"Faulkner and Desegregation" (1956), in Collected Essays, ed. Toni Morrison

(New York, Library of America, 1998), pp. 209-14.

The Fire Next Time (1963), in Collected Essays, ed. Toni Morrison (New York,

Library of America, 1998), pp. 287-347. 
Brinkley, Alan, The Publisher: Henry Luce and His American Century (New York, Vintage, 2010).

Glaude, Jr., Eddie S., Begin Again: James Baldwin's America and Its Urgent Lessons for Our Own (New York, Crown, 2020).

Nixon, Rob, Slow Violence and the Environmentalism of the Poor (Cambridge, MA, Harvard University Press, 2013).

Phillips, Caryl, A New World Order (New York, Vintage, 2002).

Thorsen, Karen (dir.), James Baldwin: The Price of the Ticket (1990), Maysles Films \& PBS/ American Masters.

The World I Never Made, C-SPAN (10 December 1986), www.c-span.org/video/?150875-1/ world-made (accessed 23 April 2021).

\section{Contributor's Biography}

Robert Jackson is the James G. Watson Professor of English at the University of Tulsa, where his work explores interdisciplinary connections among literature, film and media, and social history in the modern and contemporary United States. His most recent book, Fade In, Crossroads: A History of the Southern Cinema (Oxford University Press, 2017), considers the varied relations between Black and white southerners and the motion picture medium from the silent era to midcentury. He has edited special issues of The Faulkner Journal and The Global South, and has contributed articles and reviews to Modernism/modernity, Modern Fiction Studies, James Baldwin Review, The Faulkner Journal, Southern Literary Journal, Journal of American History, Journal of Southern History, Virginia Quarterly Review, Mississippi Quarterly, and other publications. Currently, he is at work on a book about James Baldwin's relationship with Robert F. Kennedy, particularly in the context of their infamous but mysterious May 1963 meeting to discuss the state of American race relations with a group of Baldwin's friends and associates. 